\title{
UNDERSTANDING WEB 2.0: THE EXTENSIONS OF EMOTIONAL RELEASE AND STATUS: USES AND GRATIFICATION THEORY IN THE CONTEXT OF KASHMIR
}

\author{
MUJEEB LIYAKAT
}

Assistant Professor, Department of Journalism and Mass Communication,

Islamic University of Science and Technology, Awantipora, Kashmir, India

\section{ABSTRACT}

There is no denying the fact that what is the importance of Social Media in our lives in the contemporary society. It has the power to influence the Fourth Estate. People use it to gratify their needs. They are able to release their emotions through this potent media. If their emotions are suppressed by banning of social media, it resulted in uncontrolled dangerous problems. In Kashmir, we witnessed the 150 days non-stop blockages of social media by Jammu and Kashmir government in 2016. The people of Kashmir witnessed this process of banning 28 times over the last five years. In the current year, i.e. 2017, the incumbent government has ordered the internet service providers to again block 22 social media websites. It was criticized by every section of the society. This makes the present study very important to know what gratifications people of Kashmir miss the most when social media is banned.

KEYWORDS: Social Media, Emotional Release, Status \& Kashmir

Received: Aug 03, 2017; Accepted: Aug 23, 2017; Published: Sep 16, 2017; Paper Id.: IJCMSOCT20174

\section{INTRODUCTION}

Web 2.0 is the matured stage of the development of the Internet, characterized by the transformation from static web pages to user-generated content. People were restricted to the passive viewing of content in the budding phase of internet. This one-way passive viewing era was replaced by Web 2.0; it introduces users to interact with one another. People are no more passive in this revolutionary movement. Web 1.0 was merely available for reading the content, whereas in Web 2.0; users were encouraged not only for commenting on published content but by creating the content. (O'Reilly, 2009).

Social media are interactive (two-way) and participative web 2.0 internet-based applications. Usergenerated content is an integral part of social media. (Obar and Wildman, 2015).

According to S.M. Khan, social media is undoubtedly a potent means not only to arm the people with one of the most powerful tools of mass communication but has also proved that it has the power to influence newspapers and broadcast media. (TCN, 2015).

\section{Uses and Gratification Theory}

Uses and Gratifications theory are a people-oriented approach to understanding mass communication. (Severin and Tankard, 1997). 
Shifting from other media effect theories that question what does the media do to people? UGT focuses on what do people do with media? Why do people use media and what do they use them for? (Katz, 1959).

This theory assumes that people are not passive consumers of media, but are responsible for using media to meet their desires and needs, so that they achieves gratification. (Katz, Blumler and Gurevitch, 2011).

According to West and Turner (2010) said that started in the forties of the last century, researchers began to undertake studies in radio listeners. At that time radio was seen as the most potent medium of mass communication. In 1944, with the help of interview method, Herta Herzog, in conversation with soap opera fans came to know that, three types of gratifications listeners get from using soap opera on the radio. She identifies following three gratifications: emotional, wishful thinking and learning. West and Turner further added that this theory is an extension of Abraham Maslow's Needs and Motivation Theory identified in 1954.

They further added that Dennis McQuail, Jay Blumler and Joseph Brown in 1974 identified 4 categories of gratifications. They are diverted, personal relationships, self-identity and surveillance.

\section{Rationale of the Study}

Kashmir witnessed the five-month blockage of the internet in 2016. This step was taken by the Jammu and Kashmir government. In the fourth month of current year, i.e. April 2017, the same government has ordered the internet service providers to again block 22 social media websites. The people of Kashmir witnessed this banning process 28 times over the last five years. This did not go unnoticed. Every section of the society criticizes the government's decision to block social media sites. (Yasir, 2017).

Bill Clinton once identified the most dangerous place on earth. That place was none other than Kashmir. According to Selvaraj (2016), Clinton's evaluation stands true even in the contemporary times.

New York witnessed a newspaper strike in 1945. Bernard Berelson, who is considered as the father of content analysis in communication research, undertook research on What's Missing the Newspaper means. In his study, he analyzed how people felt when they were unable to get their newspaper. He takes the use of extensive interviews. He concluded that What's Missing the Newspaper means a lot to people. He studied following things- information about public affairs and their interpretation, daily living tool, for respite, for social prestige and last but not least social contact. (Bentley, 1998).

In the present study, researcher took inspiration from Bernard Berelson's study.

The researcher wants to know what people miss during the banning of social media in Kashmir.

\section{LITERATURE REVIEW}

The Overall Fourth Estate is broadly divided into three parts: traditional media, mainstream media of the $20^{\text {th }}$ century and the emerging social media of the $21^{\text {st }}$ century. Social media is the means whereby discourse is no longer produced by individuals, but is continuously modified by all users in an interactive and participatory way. It has welcomed the common man into the media scene. Conscious of the power of social Media, the government has tried to restrict it. There is no denying the fact that it is a powerful new communication tool. (Menon, 2014).

Because of this potent media, common man conveys their message to the world and succeeds in galvanizing 
global support. (Gustin, 2011).

Social media are considered as a public sphere. Now let us throw some light on Public Sphere.

\section{SOCIAL MEDIA AS PUBLIC SPHERE}

The public sphere is defined as an area where all members of the community having access to it. Hauser (1999) defined it as a discursive place where individuals and groups gather to discuss matters of common interest and where they reach a common agreement.

Habermas (1991) defined it as a field of our social life where public opinion can be formed and access is available to all citizens. It is a place where people could share their opinions and discuss important problems and where people were able to criticize freely from state and corporate. Public Sphere is a space where the vital public opinion could be formed freely.

According to Fulya Sen (2012) Public Sphere is accessible to all citizens where they could freely sans any force shape their opinions.

Habermas's theory is relevant in contemporary media studies when discussing social media. He added that the public sphere should include the possibility for everyone to participate. This statement is reinforced by large number of scholars.

Fulya Sen (2012) concluded that, powerful Internet has helped people on the lower end that normally have no part in the mainstream public sphere. They easily interact with others through social media. She further added that the Internet is being similar to a public sphere identified by Jurgen Habermas.

Ubayasiri (2006) identifies similarities between Internet and Habermas's public sphere. He states that the Internet is quite similar to the public sphere in the sense that is providing a forum for people to participate.

Fuchs (2014) believes that social media possess the potential of becoming a public sphere.

\section{Social Media as Cathartic}

Catharsis is the process of venting where anger finds a way to release. In other words, where we get rid of emotions, when we say that something is cathartic, it means that it released emotion. When emotions are released, it decreases the tension and pressure on the person, so that they possess fewer negative emotions and are less aggressive. Sigmund Freud was the first to use catharsis theory. It states that expressing emotions like aggression and anger can reduce the feeling of aggression.

People released their aggression like anger and hostility through the use social media. Process to intentionally release emotion when they arise, developed by Lester Levenson, is found very effective technique. He found three ways of handling a feeling. We can suppress the feeling. But suppressed feelings do not fade away. They build up and become more intense inside, causing a number of uncontrolled dangerous problems, i.e. stress anxiety, tension and depression. The energy these suppressed feelings created are found very repressive and that eventually drives you to behave in ways which you have no control over.

The second way is to express the feeling. As a result, you feel better because it puts your feeling into the act. Last but not least the third common way is by trying to distract you from the emotion. But here in this step, despite our 
endeavours to escape the emotion, the emotions are there, and still take their presence in the form of stress. (Gross and Levenson, 1993).

According to finding of Facebook COO Sheryl Sandberg, the world has become social. Females are found to be more social than males. Experts believe that women use social media as a tool to make connections. (Goudreau, 2010).

Tannen (1990) coined the term Genderlect to describe the way that the conversation of men and women are completely different. Women have a deep propel to seek connection. While as men have a deep propel to seek status.

Maslow (1954) gave the hierarchy of needs, in which he gave a vital need i.e. Esteem. He identified two versions of esteem needs- lower and higher. The lowest form of esteem is the need defined as- we want respect from others through status, recognition, fame, prestige and attention. Maslow further added that if this need is deprived, it may lead to an inferiority complex, weakness and helplessness.

Maslow's thought was further reinforced by Packard (1957) when he identified eight hidden needs that we all possess. After gone through all these eight needs thoroughly, the researcher correlates one of his eight needs to status i.e. Ego Gratification

\section{RESEARCH METHODOLOGY}

The sampling method used in the present study is Convenience sampling. It is alternatively called availability sampling method, where the first available primary data source is used for the research. This method involves getting participants for the study wherever you saw them and wherever is convenient. (Thornhill, Lewis and Saunders, 1997).

The data were collected through survey among the students within the age group of 18-25 years to understand their perception of what they miss the most when social media is banned. For this, the researcher picked up respondents randomly. The researcher asks them open ended questions. Open ended questions allow respondents to include more information, including feelings, attitudes and understanding of the subject. This allows researchers to better access the respondents' true feelings on an issue. Closed- ended questions because of the limitation of the answers may not offer the respondents' choices that actually reflect their real feelings.

In a pilot study, Researcher asks the sample the open-ended questions. The next step on the basis of these open ended questions, the researcher categorizes their gratifications obtained from social media in five categories: Emotional Release, Status, Entertainment, Sociability and information seeking. The sixth category identified was Neutral, who do not use social media comes under this category.

\section{Entertainment}

Those who have escaped from the pain and stresses of daily life, and have read and discussed, about page 3 journalism. Talking about movies, music, fun and food.

\section{Emotional Release}

Those who release their emotions, through social media.

\section{Sociability}

Enhance social interaction. 


\section{Social Status}

Those who can earn their social status, by showing achievements.

\section{Information Seeking}

To be informed and educated.

\section{Neutral}

Those who do not use social media.

The researcher has selected one district from South Kashmir, one district of Central Kashmir and one district from North Kashmir. The selected districts are Anantnag, Srinagar and Baramulla. Samples were taken from 3 universities falling in these three districts. Islamic University of Science and Technology was taken from South Kashmir, University of Kashmir was taken from Central Kashmir and North Campus of Kashmir University was taken from North Kashmir. 50 respondents were interviewed from each district. On the basis of Genderlect Theory, the sample is further divided into 25 boys and 25 girls. Respondents were selected randomly. They were interviewed at University canteens, University lawns and outside classrooms.

The researcher first undertook a pilot study and came to know that what the majority of the students missing the most is emotional release and status. What males miss the most is emotional release and females miss the most is social status. Then the researcher chooses this need to fit in the title of the research paper also. Marshal McLuhan, who is universally, regarded as the father of communications and media studies and the prophet of the information age wrote a piece of art in 1964 entitled Understanding Media: The Extensions of Man. The title of the research paper got inspired from this book.

\section{OBJECTIVES}

To know what students miss without social media.

To know what male students miss the most and what female students miss the most.

\section{HYPOTHESIS}

After reviewing the available literature and undertaking pilot study, researcher drafts the hypothesis, that men and women have different criteria of using social media.

Male students miss most the emotional release and female students miss social status when government bans social media.

\section{FINDINGS}

Table 1: Percentage of Males and Females Usage of Social Media in South Kashmir (SK), Central Kashmir (CK) and North Kashmir (NK)

\begin{tabular}{|c|c|c|c|c|c|c|c|c|c|c|c|c|c|c|c|c|c|}
\hline \multicolumn{6}{|c|}{ EMOTIONAL RELEASE } & \multicolumn{6}{|c|}{ STATUS } & \multicolumn{6}{|c|}{ ENTERTAINMENT } \\
\hline & ALE & & FEM & ALES & & MA & ES & & FEM & LES & & MA & LES & & & IALE & \\
\hline SK & CK & NK & SK & CK & NK & SK & CK & NK & SK & CK & NK & SK & CK & NK & SK & CK & NK \\
\hline 40 & 35 & 35 & 20 & 15 & 15 & 15 & 15 & 15 & 40 & 40 & 35 & 10 & 10 & 10 & 10 & 10 & 10 \\
\hline
\end{tabular}


Table 2

\begin{tabular}{|c|c|c|c|c|c|c|c|c|c|c|c|c|c|c|c|c|c|}
\hline \multicolumn{6}{|c|}{ SOCIABILITY } & \multicolumn{6}{|c|}{ INFORMATION SEEKING } & \multicolumn{6}{|c|}{ NEUTRAL } \\
\hline \multicolumn{3}{|c|}{ MALES } & \multicolumn{3}{|c|}{ FEMALES } & \multicolumn{3}{|c|}{ MALES } & \multicolumn{3}{|c|}{ FEMALES } & \multicolumn{3}{|c|}{ MALES } & \multicolumn{3}{|c|}{ FEMALES } \\
\hline SK & CK & NK & SK & CK & NK & SK & CK & NK & SK & CK & NK & SK & CK & NK & SK & CK & NK \\
\hline 15 & 10 & 15 & $\mathbf{1 0}$ & 15 & 10 & 10 & 15 & 15 & 15 & 15 & 20 & 10 & 15 & 10 & 5 & 5 & 10 \\
\hline
\end{tabular}

\section{ANALYSIS}

The above study takes into account the three universities of Kashmir falling in North, Central and South Kashmir. The study came to know that when Emotional Release category was put into account, it was found that males account for 40, 35 and 35 percent in South, Central and North Kashmir. When the present study has been taken into account, the Status category, it was found that males account for 15 percent in all the three areas of Kashmir. Entertainment means to men only 10 percent in the sample areas. Now take the sociability, men occupy the 15,10 and 15 percentage. Information Seeking accounts for 10,15 and 15 percent. The last category i.e., Neutral accounts for 10,15 and 10 percentage. It is clear from the above study that men use social media for emotional release. The second hypothesis is accepted.

When the researcher compares male versus female usage of social media in terms of emotional release, it was found that male accounts for 40, 35 and 35 percent while as females account for 20,15 and 15. Males were found to be more indulged in the emotional release category as compared to females. Our second hypothesis is again accepted.

When Status category was analyzed, it was found that females accounts for 40, 40 and 35 percent. On the contrary, males account for 20,15 and 15. It is found that females use social media more than the males, when Status is considered.

From the above findings, it is also transparent that men and women use social media for different purposes. Alternative hypothesis are fully accepted.

\section{CONCLUSIONS}

Review of literature reflects that Kashmir is the most dangerous place on earth. If the complete ban on social media will not be lifted, a day will come when people of Kashmir will be considered, as the most dangerous people on earth. If people will release their aggression like hostility and anger, through the use of social media, suppressed feelings do fade away, and then they will live a normal life happily. If their feelings are suppressed by banning social media, suppressed feelings build up and become more intense inside, causing a number of uncontrolled dangerous problems. Social media is cathartic for them. With the help of social media, they release their emotions and their anger, hostility and aggression are released. So, for the betterment of the people of Kashmir, social media should not be banned and try the best to make social media, the cathartic for them. Most of the males, make it cathartic for the emotional release and most of the females, make it same for the social status.

\section{LIMITATIONS}

This study was limited to only three Universities in Kashmir division.

This study was limited to only 150 respondents. To know it on a grand scale, the researcher in future will do a census inquiry of all the students of the universities of Kashmir. 
This study was limited to Universities only; it cannot be generalized to colleges, higher secondary, high schools, middle schools or primary schools.

This study was limited to Kashmir division only.

\section{SUGGESTION}

The need of the hour is to pursue research on aggression level of the people of Kashmir since the banning of social media. Because Sigmund Freud states that expressing should reduce the feeling of aggression.

\section{REFERENCES}

1. Bentley, Clyde. (1998). 50 years later: What's Missing The Newspapers Now. http://www.academia.edu/l1684862/50_years_later_What_Missing_the_Newspaper_Means_Now_Berelson_dependency_theo ry_and_failed_newspaper_delivery

2. Fuchs, C. (2014). Social Media and the Public Sphere in Open Access Journal for a Global Sustainable Information Society. $12(1)$.

3. Fulya Sen, A. (2012). The Social Media as a Public Sphere: The Rise of Social Opposition in International Conference on Communication, Media, Technology and Design. http://www.cmdconf.net/2012/makale/92.pdf

4. Goudreau, Jenna. (2010). What Men and Women are Doing on Facebook. https://www.forbes.com/2010/04/26/popular-socialnetworking-sites-forbes-woman-time-facebook-twitter.html.

5. Gross, J. J., \& R.W. Levenson. (1993). Emotional suppression: Physiology, self-report, and expressive behavior. Journal Of Personality \& Social Psychology, 64 (6).

6. Gustin, Sam. (2011). Social Media Sparked, Accelerated Egypt's Revolutionary Fire. https://www.wired.com/2011/02/egyptsrevolutionary-firel

7. Habermas, Jurgen. (1991). The Structural Transformation of the Public Sphere. Cambridge: MIT Press.

8. Hauser, G. (1999). Vernacular Voices: The Rhetoric of Publics and Public Sphere. Columbia: University of South Carolina Press.

9. Katz, E. (1959). Mass Communications Research and the Study of Popular Culture: An Editorial Note on a Possible Future in Studies in Public Communication, 2 1-6. Retrieved from http://repository.upenn.edu/asc_papers/165

10. Katz, Elihu, Jay G. Blumler, and Michael Gurevitch. (1974). Uses and Gratifications Research in The Public Opinion Quarterly 4th ser. 37 (1973-1974): 509-23. JSTOR. Web. 14 Oct. 2011. < http://jstor.org/stable/2747854

11. Maslow, Abraham. (1954). Motivation and Personality. New York: Harper and Brothers.

12. Menon, K.S.R. (2014). Social Media as a Powerful New Communication Tool. http://mediamagazine.in/content/social-mediapowerful-new-communication-tool

13. Obar, Jonathan and Steve Wildman. (2015). Social media definition and the governance challenge: An introduction to the special issue. Telecommunication policy. 39(9). Doi:10.1016/j.telpol.2015.07.014

14. O'Reilly, Tim. (2009). What is Web 2.0. California: O'Reilly Media, Inc

15. Packard, Vance. (1957). The Hidden Persuaders. New York: Ig Publishing. 
16. Selvaraj, Sudhir. (2016). Kashmir: 'The most Dangerous place on Earth. www.globalchristiannews.org/article/kashmir-astrategic-analysis/

17. Severin, Werner and James Tankard. (1997). Communication theories: Origin, Methods and Uses in the Mass Media. London: Longman.

18. Tannen, Deborah. (1990). You Just Don't Understand. New York: Ballantine

19. TCN News. (2015). Social Media a powerful mass communication tool to arm the people. http://twocircles.net/2015apr21/1429629781.html

20. Thornhill, Adrian, Philip Lewis and Mark Sanders. (2012). Research Methods for Business Students. London: Pearson Education Limited.

21. Ubayasiri, K. (2006). Internet and the Public Sphere: A glimpse of YouTube in Central Queensland University. http:/lejournalist.com.au/v6n2/ubayasiri622.pdf

22. West, Richard and Lynn Turner (2007). Introducing Communication Theory. New York: McGraw Hill

23. Yasir, Samir. (2017). Social Media banned in Kashmir Valley. http://www.firstpost.com/india/social-media-banned-inkashmir-valley-bizmen-students-question-motive-say-it-will-impact-economy-3407546.html 